\title{
Motivation and Intervention in the Northern Ireland
}

\section{Peace Process: An Interview with President Clinton}

\section{Graham Spencer}

\begin{abstract}
The role of former United States President William Jefferson Clinton in the Northern Ireland peace process has been widely acknowledged as an example of risk-taking, political leadership and diplomacy that is representative of strategic post-Cold War aims. However, the tendency to see Clinton's role from the perspective of international and global policy objectives has hindered consideration of his motivational role in the Northern Ireland peace process, as well as he how moved between encouragement and intervention to help the political parties reach a settlement. This article, which draws from an extended interview conducted with Clinton in 2017, seeks to develop a more comprehensive picture of Clinton's participation in the peace process and argues that his success in helping to broker the Northern Ireland peace deal came from a connection between motivational and interventional roles. It also argues that the cumulative effect of these two types of engagement enabled him to help convince others of the need to take risks for peace and gave him greater influence and, indeed, leverage over the peace process as a result.
\end{abstract}

\section{Introduction}

In a speech that he gave in Belfast, Northern Ireland's capital city, during his first visit to Northern Ireland in November 1995, U.S. President Bill Clinton expressed hope for peace and the need to grasp the opportunity offered by an emerging peace process. Seeking to bring 
together the symbolism of two competing cultures, Clinton proclaimed how "In the land of the harp and the fiddle," "the fife and the Lambeg drum, two proud traditions are coming together in the harmonies of peace." (1995). Such a peace, Clinton continued, would require the people of Northern Ireland to have "open minds" and recognize engagement in dialogue as "an act of strength and common sense" rather than an act of surrender.

Those who refused to relinquish past enmity, Clinton warned, would "Never escape the dead-end street of violence. But you, the vast majority, Protestant and Catholic alike, must not allow the ship of peace to sink on the rocks of old habits and hard grudges" (Clinton 1995). He went on "Your destiny is for you to determine. Only you can decide between division and unity, between hard lives and high hopes, only you can create a lasting peace. It takes courage to let go of familiar divisions. It takes faith to walk down a new road" and "strength to keep moving forward" (Clinton 1995). Embracing change, for Clinton, therefore meant imagining a future without the animosities of the past, and his speech was designed to give emphasis to that possibility through emotional appeal.

In contrast, and in a speech he delivered in 2003 (published in 2013), Clinton identified three imperatives that were representative of his own involvement in the Northern Ireland peace process. The first is that it is necessary to work through difficulties if one is to build friendships and deepen relationships. The second is that one should not presume to know the positions and concerns of parties in conflict but engage in intense listening to learn and understand those positions and concerns. And the third is that one should understand that "all politics is local," and so remain alert to the impact of local reactions on wider national issues (Clinton 2013.).

The two speeches above highlight two kinds of leadership: one motivational and the other educational. The first relies on emotion and the second relies on understanding. The 
first has hope and vision to depict a better future and the second presents the practical considerations needed to reach that end.

The first speech, which Clinton gave two years into his presidency, provided a spiritual emphasis on the peace process and was theatrical in presentation. The second speech, which Clinton gave two years after leaving office, offers instruction on the mechanics needed to make peace real. This tendency to inspire in relation to political calculation indicates a possible interaction between the personal and the political that is of concern in this article.

Though Clinton's intervention in Northern Ireland many have come from a personal fascination about ending that conflict and was influenced by his own civil rights convictions (Dempsey 2004: 199), it was also representative of a wider strategic shift that emerged in the new post-Cold War world. Now freed from the enduring threat of communism, and the traditional U.S. policy of containment that had been used to confront that threat, Clinton was able to extend U.S. influence through a process of 'democratic enlargement' (Brinkley 1997) and use economic development to generate diplomatic advantage because of it (MacLeod 2016:). This new period gave Clinton the opportunity to challenge the expectations of diplomatic conduct (as was the case, discussed more fully later, with the British when Clinton granted Sinn Fein president Gerry Adams a visa to enter the U.S. in 1994 (Renwick 2019: 211-218)) and gave him more flexibility to deal with international affairs as a result (O'Grady 1996: 6).

Given that the post-Cold War world made it harder to sustain claims that national political interests would remain unchanged because of those (particularly communists) perceived as a permanent threat (Cox 1998: 60) Clinton proposed to make foreign policymaking more proactive and less reactive (Brinkley 1997: 114) and used market expansionism as the key mechanism for achieving this. 
Though Clinton stressed the value of relationships and "the human drama of the peace process" (MacLeod 2016: 235), and this indicated the value for him of soft power and personal diplomacy (Riley 2016: 230), it is clear that the process developed through intensive political activity. The origins of it emerged in the late 1980s as a series of confidential dialogues, strategic statements, and confidential meetings held in Northern Ireland, the United Kingdom, and the Republic of Ireland (Hennessey 2000; Spencer 2008; 2015a; 2015b). But, the process can also be seen as a response to a centuries-old religious conflict between Protestants and Catholics that evolved into a violent struggle between Protestant unionists seeking to remain British and Catholic nationalists seeking unification with the Irish Republic.

During the conflict's modern period known as "the Troubles," which began as a response to civil rights discrimination against Catholics in the late 1960s, two serious attempts to build peace took place that failed to bring about a substantive resolution. The first, when moderate unionists and nationalists agreed to form a power-sharing Northern Ireland Executive at Sunningdale, England in 1974, that foundered because of wider unionist resistance to what was seen as a dilution of political and social power and the British Government's failure to adequately support it (Anderson 1994; Hennessey 2015; McDaid 2016; Dorr 2017). And second, the Anglo-Irish Agreement of 1985, when the British and Irish governments collaborated to bring about (FitzGerald 1991; Lillis and Goodall 2010), closer ties between the Republic of Ireland and the UK through a framework that prioritized self-determination, consent, and democratic participation (Bew and Gillespie 1999).

Though the Anglo-Irish Agreement allowed greater Irish involvement in the affairs of Northern Ireland and presented opportunities for nationalists to try and work for a united Ireland because of that involvement, it was this very possibility that angered unionists and led them to conduct huge public protests in opposition to it. Relations between the unionists and 
the British government effectively froze for four years until, in 1989, British Secretary of State Peter Brooke encouraged unionists to engage in a talks process to try and negotiate a new power-sharing arrangement in Northern Ireland that would address fears about Irish interference there. It would be these talks that would later lead to the later more comprehensive negotiations that resulted in the Good Friday Agreement of 1998 (Bloomfield 1998).

Interestingly, it was the failure of Sunningdale that prompted Irish political and diplomatic pressure on President Jimmy Carter to announce an initiative on Ireland based on human rights and economic investment in 1977 (Dumbrell 1993: 130-141; FitzPatrick 2017: 62-70). The Anglo-Irish Agreement was also achieved because of presidential pressure, with President Ronald Reagan exploiting his strong personal relationship with British Prime Minister Margaret Thatcher in order to get her to support the agreement. Thatcher later admitted: "It was pressure from the Americans that made me sign that Agreement" (McAlpine 1997: 272).

Unlike Sunningdale and the Anglo-Irish Agreement, which, in the case of the former was negotiated by moderate unionists and nationalists, and, in the case of the latter, was negotiated by the British and Irish governments, the peace process was embracive in design and intent. The architects of the process recognized that for peace to hold it had to be as inclusive as possible and that even the proponents of violence needed to come into the democratic process and agree to non-violent representation - and to persuade their followers to do the same. For Sinn Fein and the Provisional Irish Republican Army (PIRA) U.S. involvement would be central in this transformation, and Clinton skilfully persuaded republican leaders to appreciate the risks that they needed to take to achieve peace, acknowledging that this was more likely to happen if republicans were part of a broader nationalist front at the same time (Adams 1996: 322). 
In this article, I will seek to explore how Clinton used his motivational and political skills to persuade political players to reach a peace settlement and so claim diplomatic success that was consistent with his own political foreign policy goals. First, I describe the political context that informed Clinton's actions before offering some tentative thoughts on the role of mediation in negotiations more generally. That discussion is followed by an interview with Clinton in which he describes his involvement in the Northern Ireland peace process.

\section{Clinton's Involvement in Northern Ireland: The Political Context}

President Clinton made a commitment to become involved in the Northern Ireland issue before he was even elected president. In April 1992, on the campaign trail, he attended an Irish-American forum in New York and was asked if he would grant Gerry Adams of Sinn Fein (the republican party believed to be the political wing of the PIRA) a visa to enter the U.S. if he were to become president. This would help internationalise Sinn Fein and enable its leaders make a more compelling case to their supporters that politics would be more beneficial to their objective of achieving Irish unity than violence (many accusers also claimed that Adams had been a member of the PIRA, the secret paramilitary organization, which contributed to the controversy over granting him a visa). This move had also put candidate Clinton's interest in the Irish peace process more firmly on the political agenda in Washington (O’Dowd 2010; O’Hanlon 1998).

Representatives from legal and media worlds, as well as leaders of prominent IrishAmerican groups (O’Clery 1997: 13-32; Mallie and McKittrick 2001) (and where commitments agreed by Clinton in 1992 on the campaign trail were later acknowledged by him as the main reason for his involvement in the peace process (Clinton 2004)) pressed 
Clinton at the forum to accept the need for an Adams visa, which he did while being unaware of the political difficulties it would later create (Mallie and McKittrick 2001). Clinton also committed to an economic envoy for Northern Ireland to source investment opportunities and contribute economic support as part of a broader "commercial diplomacy" initiative to build economic incentives into the political process (Soderberg 2005).

The issues surrounding a visa for Adams were especially contentious given the belief that Adams was acting not just as a Sinn Fein politician but as one of the most senior members of the PIRA, and it was not granted until February 1994, more than one full year into the Clinton administration (indicating how contentious this was). Those who opposed the visa within the U.S. Department of State and the U.S. Department of Justice, along with intense British diplomatic activity to try and block it, reflected the view that it would harm the special relationship between the U.S. and the UK and also suggest to international audiences that the U.S. was softening its stance on terrorism.

However, following intense behind-the-scenes activity, in January 1994, some fifty signatories from the United States Senate and the House of Representatives led by Democrat Senator Edward M. Kennedy ${ }^{i}$ sent a letter of support urging Clinton to grant the visa and encouraging him to help facilitate the emerging dialogue. The intense activity to secure a visa for Adams was in part to pressure both the PIRA and the British to engage in a serious negotiation process (Adams 1997: 65-66). Letting Adams visit the U.S. conferred some degree of legitimacy on the republican cause, while enabling greater American influence over Sinn Fein in the process (Clinton 2004).

Although Clinton's decision to engage more directly with the peace process did no harm to his popularity among Irish-American voters and this may have helped motivate his engagement (Clinton 2004), it this does not appear to have been the primary impetus. Indeed, Clinton worked directly with all key participants in Northern Ireland, thereby subverting 
claims that he represented only the preferences of Irish-Americans, which were largely republican-leaning, and minimising possible accusations that he was favouring those with most to gain from the changes that a peace process might bring (Guelke 1996; Dumbrell 1995: 125).

Working with the political parties and the British and Irish governments in this way allowed the U.S. to "wield its influence more broadly" and indicated an intention to "nudge rather than instruct, to entice rather than threaten" (Hazleton 2000: 119). Clinton's Deputy National Security Advisor Nancy Soderberg (2005: 74) wrote that such an approach "became critical in building confidence among the parties" because "while neither side trusted any commitments made to each other, any commitments made to the U.S., especially the President, could be trusted", reinforcing an image of the U.S. as a credible third-party to negotiations.

American involvement brought leverage to bear on Sinn Fein and the PIRA to deliver a ceasefire in August 1994 (O'Dowd 2010). Following the advice of those such as Nancy Soderberg, Tony Lake (Clinton's National Security Advisor) and Senator Edward Kennedy Clinton chose to override the advice of the United States Department of State that he should not disturb the country's status quo position of support for British policy on Northern Ireland. As part of a new strategy emphasizing "non-traditional, non-executive sources of power" (Lynch 2004: 142), Clinton and his team persuasively represented established foreign policy positions as "tired and stale" and adopted a new "policy entrepreneurialism" to shape and inform the conduct of foreign relations (Lynch 2004).

That Clinton was able to upset the British by granting the Adams visa (Major 1999; Seitz 1998) and then quickly overcome the resulting tensions to pursue a productive relationship illustrates how he viewed political relations not just in terms of policy, but through inter-personal dynamics (Lynch 2004). Clinton made three visits visit to Northern 
Ireland during his two terms in office. His first one, in November 1995, in which he was greeted with considerable public acclaim, was especially representative of his convergent political and personal diplomacy approach and its success can be seen as a justification of that approach (Birney and O’Neill 1997).

With his visit to Northern Ireland, Clinton also sought to eclipse the memory of recent diplomatic setbacks in the Israeli-Palestinian conflict. In September 1993 he had welcomed Yitzhak Rabin, the Prime Minister of Israel, and Mahmoud Abbas, the negotiator for the Palestine Liberation Organization (PLO) leader, to the White House for the signing of the Oslo Accords. The now iconic image of Clinton with arms outstretched embracing Rabin and PLO leader Yasir Arafat was symbolic of his peace-making agenda. But the Oslo process came to a halt when Rabin was assassinated just a few weeks before Clinton's visit to Northern Ireland.

Furthermore, Clinton's commitment to Northern Ireland did not wane after the Canary Wharf bombing of February 1996 - which Clinton discusses in the following interview - and indeed intensified following the elections of Tony Blair as Prime Minister of the UK and Bertie Ahern as Taoiseach (prime minister) of Ireland in spring 1997. To illustrate this intensification U.S. aides working with Senator George Mitchell in the negotiations told the political players that if an agreement was to be reached it would almost certainly be concluded quickly (this was particularly the case once Mitchell had formally announced to the political parties at the end of March a deadline for agreement of 9 April 1998 (Mitchell 1999:144-146)), and so full and committed participation would be vital if interests were to be protected in any final outcome (Pope and Pozorski 2009). The speed of the process in its concluding phase and the anxiety this created for the parties led to that Clinton being constantly available by phone to reassure political leaders and respond to their difficulties. He did this mostly by pointing out the difficulties faced by others and asking each to empathize 
with those who were dealing with internal party differences about what to accept and not accept (this was particularly so with unionist concerns; see Mallie and McKittrick 2001: 248).

The political parties in the negotiations that led to the Good Friday Agreement of 1998 were participants in a new atmosphere of possibility that reflected the "constructive ambiguity' of the period (Spencer 2010). Further, the inclusive nature of the process meant new forms of political representation (such as the Northern Ireland Women's Coalition, which had formed to be part of the negotiations (Fearon 1999)) could develop. Tony Blair's chief of staff Jonathan Powell stressed that the Good Friday Agreement "was an agreement to disagree" (Powell 2008: 108) since it provided the space for different interpretations of the agreement that each political party could use to claim success and bring its respective constituency support along. However, once the Good Friday Agreement was reached and clearer understanding of what it would need to implement became apparent, so political positions hardened sharpened. At that moment ambiguity changed from being a constructive influence to a destructive one (this can be seen from the problems that came after the agreement with regards to weapons decommissioning and new policing and justice structures that were not dealt with at the time the agreement was signed (Powell 2008: 2011-308)).

What we might also note with regards to Clinton's participation as the agreement got closer, and indeed afterwards, is how his role became more interventionist once the struggles over substance and detail deepened and the disputes over what parts of the agreement meant intensified (Mallie and McKittrick 2001: 248, 269,275). The patience that had been shown to all the political parties and had been personified by the role of Senator Mitchell, who for years had listened to endless debates about procedure and detail then changed, as momentum switched towards acceptance or not of a deal. At such a time diplomacy can shift from being empathetic and slow to intense and even coercive if participants are to finally reach a settlement (Curran, Sebenius and Watkins 2004). 


\section{Mediation and the Personal Context}

According to William Zartman and Sadia Touval (1985), a useful mediation skill is the ability to make unattractive propositions look attractive, particularly in situations of intransigence and stalemate. To create this attractiveness a neutral third-party, who shares none of the parties' fears and enmities, can better help parties bridge positions because he does not have vested interests and so can act fairly. He is also able to motivate by presenting risks as opportunities, turning points of mutual contention into points of mutual interest and can better facilitate consensus on the need for movement.

Yet the mediator's persuasiveness also surely relates to the intensity of her personal engagement as well as her skills in constructing a powerful moral narrative that clearly describes the benefits of ending conflict and why and how the gains justify the inevitable costs. As part of this encounter the mediator seeks to generate trust, and respect and her ongoing commitment reinforces her trustworthiness and respectfulness.

That said, the successful mediator must not only advocate positive change, but help to personify that possibility and show that he too is prepared to take risks and so that the process is not without costs for him either (as noted Clinton had done this with the Adams visa (Dempsey 2004: 204)). Indeed, he must make change not only desirable but necessary, and to do so he must impress on the participants the need for urgency to conclude a resolution. Yet to gain a wider acceptance of this urgency perhaps he must also emphasize political decisions as emotional convictions and so encourage participants to move when their political impulse is to resist moving. He must present risks as essential steps and help participants take those steps to show he is trusted as a participant in the change he advocates. He must therefore demonstrate a personal commitment to what he is telling others to do and continue to try to make them feel that difficulties must be faced and overcome for a greater good. 
It is important to note that mediation styles vary with personalities, circumstances and strategies. As Curran, Sebenius and Watkins discovered when they compared the approach of Mitchell in Northern Ireland to that of Richard Holbrooke who negotiated the Dayton Accords that ended the Bosnian conflict, Mitchell's approach was one of patience and gradualism while Holbrooke's approach was more aggressive (Curran, Sebenius and Watkins 2004). Making comparisons here is not without problems given the differences of the two processes. Dayton was conducted speedily in a remote location, was focussed more on bringing about a ceasefire and ensuring separation of the warring factions, and was used by western peacekeeping forces to monitor an end to hostilities by holding the factions to account if they violated the terms of the agreement. It was also dealing with a much wider problem of potential escalation (Jackson 2007: 197, 201) than was the case in Northern Ireland, where tensions were more contained, the conflict had been running much longer and the climate had been discernibly shifting towards a growing receptiveness for a peace settlement since the late 1980s (Hennessey 2000).

For Clinton, emotional diplomacy and motivation were vital to his credibility as a mediator in the peace process (Hall 2015). Clinton saw that emotion was central to political transformation but he also had to show conviction. By making himself available at times of great inconvenience (such as staying up all night to take phone calls from the political leaders) he was able to develop trust and confidence in his role (I have interviewed many of the key players in the peace process and their opinion on Clinton's role is overwhelmingly positive (Spencer 2019)).

On this, and as Zartman and Berman note, "Trust is enhanced if a negotiator can demonstrate a genuine interest in trying to help the other side reach its objective while retaining his own objective and making the two appear compatible" (Zartman and Berman 
1982: 33). In such a situation "interdependence is increased" (ibid: 37), making betrayal less likely.

Clinton's preference was not to prioritize emotion over political decision-making but to see the political challenges of reaching peace in terms of emotional traction, and to help do this he used empathy "to infer intentions, motivations, positions and interests" in order to build more collaborative relations (Holmes and Yarhi-Milo 2017: 107). He saw empathy as a tool for acknowledging participants' differing perspectives and concerns but was able to incorporate those concerns into the vision he promoted of a peaceful, stable future.

Inevitably, Clinton also used his authority and status as president of the United States to "reinforce his logic and charm" (Neustadt 1990: 30) in service of a policy agenda. Like other presidents before him, he saw that "the power to persuade is the power to bargain" (Neustadt 1990: 32). In addition, Clinton's involvement in the peace process exemplified his vision of a new international diplomacy that applied persuasion and "soft power" techniques (i.e. listening, offering recognition, and demonstrating respect) rather than just coercion and the threat of hard power (Nye 2005). This more reconciliatory approach (Dobson 2014), helped Clinton extract support for his own recommendations, if not always as quickly or as comprehensively as he would have liked, and demonstrated the new American diplomatic emphasis in the process. An emphasis that would give attention to trust, empathy, and supportive engagement but would not jettison the need for more assertive forms of intervention in international crises as and when required (and as the Holbrooke negotiations show).

\section{Clinton and Northern Ireland: An Interview}


The interview that follows with President Clinton took place in October 2017. Arranged through his press office and conducted over an hour at the Clinton Foundation in Manhattan, a brief overview of the interview questions was provided in advance. This semistructured and taped interview sought to address how Clinton tried to motivate the key political players involved in the peace process and how by intervening he was better able to help convince those players to accept risks for peace. The interview is verbatim, but occasional extra detail in square brackets appears to assist better understanding for the reader.

Spencer: Can you provide some background to attending the Irish forum meeting in February 1992 when you were asked about committing to a visa for Gerry Adams and [establishing] a Special Envoy for Northern Ireland?

Clinton: Keep in mind that when we did this, the talks between the Northern Ireland parties and [UK Prime Minister] John Major's government ${ }^{\mathrm{i}}$ were not yet public, but what we wanted to do was get this thing off the dime. We realized that if I came out for an envoy it would violate a long-standing understanding between the U.S. and the UK and they [the United Kingdom] would be mad, but if we didn't, then we wouldn't be making a contribution to moving the process forward.

It was clear that something had to be done and there seemed to be some willingness in both communities to engage with this based on what all of our contacts were telling us, and they were in regular touch with people in Northern Ireland and [in] the Republic [of Ireland]. We finally decided it was worth the risk and believed that if we got lucky we might spark some sort of process of change that would actually work. The problem with just having an envoy is that, in the end, they [the parties to the conflict] have to make the peace process work so the way it developed was George Mitchell was appointed after we had a trade and 
investment conference and then we appointed Mitchell as the envoy out of that. This then gave the British some space because although we weren't declaring what the peace process would be and we weren't putting ourselves in charge of the peace process, we were nevertheless putting ourselves in the middle of the economic, social, and political life of Northern Ireland more than we had before.

Spencer: Were there a number of people in the political system that were not only unhappy about this but tried to obstruct it?

Clinton: Indeed, there was, such as, for example, the whole State Department.

Spencer: How did you field that pressure or objection? Did you just ignore it?

Clinton: No, I didn't ignore it. I tried to deal with it. The person I was most worried about, for personal reasons, was Warren Christopher, my Secretary of State. He and I were close friends, but I thought I could manage that. I was also worried about Admiral [William J.] Crowe, the Ambassador to the United Kingdom who had a good military mind and was a very shrewd diplomat. I did not want to be at crosshairs with him, but I thought I knew more about this issue than he did and I thought that if I did what he and the State Department wanted, which was to walk up to the brink one more time, something America had done repeatedly, but that I did not keep pushing forward, then not much good would happen. That tension really came to a head on the Adams visa.

Spencer: How did you gauge the risks involved with the Adams visa?

Clinton: It was significant because if the PIRA were kidding and if Sinn Fein were not really speaking for them, then we had problems. You have got to understand - we thought we knew what was going on in Northern Ireland politically and on what was going on within Sinn Fein/IRA because we had pretty good intelligence from Americans who had contacts. 
But there was still some significant risk there. I finally decided when we got a pretty clear signal from Gerry Adams that he was serious about exploring peace because we knew that this wouldn't be an easy option for him. The easy option seemed to be to just say no. The State Department said no. Even one of the most prominent Irish Americans, the Speaker of the House [of Representative] Tom Foley, said no and there were varying divisions within the Kennedy clan about whether we should say yes or no. My position was [that] if we said no we wouldn't be criticized, but we would give the people in the republican camp an excuse not to go forward.

Spencer: So was your mind made up early on about accepting the visa request?

Clinton: I wouldn't think a president can make a decision of that magnitude alone. My mind was made up to take the risk on the special envoy way back in the [presidential] primary because I wouldn't have said it if I wasn't prepared to take that risk. Sometimes, when someone gets into office, they find they can't keep a commitment made because circumstances change but, in this case, it would have been a clear back-off, and I wasn't about to do that unless there was a better alternative. Also, this came up pretty early in my tenure, although the conversations between the Major government and the Irish and the Northern Ireland parties had been going on, so my strong inclination was to do it even though there were significant risks.

I could have looked like I was a handmaiden to terrorists if it had gone wrong, and, don't forget, we had already had the first World Trade Center attack in 1993 shortly after I took office, but I had a feeling, having listened and listened and having thought about it, that this was a real opportunity. It's not fair to say that I went through a bunch of optics to reach the decision I had already reached. I owed it to Warren Christopher and, as it turned, out I owed it to Admiral Crowe and to Speaker Foley, too. 
I had a huge agenda before the Congress where I was trying to reverse twelve years of President Ronald Reagan's trickle-down economic policy. I was also trying to do a trade agreement with Mexico and Canada, which was controversial within my own party [and] which was very tough, but we had [National Security Advisor] Tony Lake, and [Deputy Assistant to the President for National Security Affairs] Nancy Soderberg and [Deputy National Security Advisor] Sandy Berger all working hard on this. The White House Foreign policy team was all in and they believed we should grant the visa based on the aggregate of conversations with the relevant parties. The State Department was getting rained down on by the British government, as indeed was Ambassador Crowe, because of this, and so there was some pressure to face down.

Spencer: Yet Patrick Mayhew, [the UK Secretary of State for Northern Ireland] was said to admit later in conversation that you made it easier for the British to engage with the PIRA because of moving in the way you did.

Clinton: They didn't know what to do and, to be fair, there was a little political rankle here which put Major in a bad position. I always felt Major should have got more credit than he got for starting this. First, because he had a much narrower mandate in the British Parliament than Prime Minister Blair did and, second, because his governing majority required the unionists to support him. I did not take any particular pleasure in making his life more difficult, but I thought that if we were to have any chance to succeed, we had to keep moving. He needed the Irish diaspora in America, and he needed all of us working hard. In other words, he needed to have enough "street cred," as we say in America, to push the republican side toward peace, which would eventually include decommissioning and all that stuff. And I thought we needed to move then, because it was never going to get any easier, so we should take the risks. 
But the other thing you should be reminded of is that Major was taking all sorts of grief to his right in the press because he had understandably been pretty open in his support for President [George H. W.] Bush when we were running. There were all these stories that the Major Government had supported the Bush campaign by looking into my passport file to see if I tried to give up my American citizenship in opposition to the Vietnam War. So the press was killing Major with this by saying it would ruin the special relationship and I was going to screw the British by dealing with my PIRA friends and all of that. The truth is I didn't give five minutes worth of thought to it. I wasn't upset by it at all. I suppose I would have been if there had been any truth to it, but since I knew the whole thing was a last-minute desperation move on the other side, I was happy for them to waste their time looking for my passport file. I thought he got an unfair press about it for a while because I would never make American policy based on personal pique like that, and I can't think why any American president would do that.

Spencer: When the visa was granted to Gerry Adams how did you see the importance of that moment in terms of leverage towards an PIRA ceasefire?

Clinton: In the background, we got as far as we could possibly get in getting a commitment that the visa would lead to a ceasefire. We weren't just messing around or posturing with no ideas. In fairness, I never felt that we were misled by either side and that the parties were straight with us. [Ulster Unionist Party Leader David] Trimble and Adams were straight with us and Hume, who was out there like a transparent umbrella for the whole thing, obviously was. When Adams said before he was able to promise us anything there were three things he had to do within the movement we found him to be truthful on that score. In time he did those things and, in the end, we got where we needed to be [which was a ceasefire, negotiations and an agreement].

Spencer: Did you face flak from people accusing you of engaging with terrorists? 
Clinton: Oh sure. Keep in mind that at the same time we were at the high-water mark of our efforts to help the Israelis and Palestinians make peace. And in September of 1993 they had come to the White House and signed the Oslo Accords peace agreement, and when Rabin was questioned and criticized about that he reminded everybody that you do not make peace with your friends. You are already at peace with your friends, you have to take chances.

So I think we had a lot of wind behind our sails and we weren't that far away from the end of the Cold War. And I think most Americans wanted their president to pull the world together now that the Iron Curtain had dropped, the bi-polar world had had its cover removed, and everybody could see both the enormous potential as well as the maddening dangers that that held. I had the feeling that people in our country, particularly when it came to Northern Ireland, wanted us to be a force for peace because of their affection and their support for people in both the UK and the Irish Republic. Although many didn't understand the nuances they knew this had been going on for a long time and was a big problem and because they liked both sides they supported me in trying to help with the peace process.

Spencer: How was [the] Canary Wharf [bombing] received in $1996 ?$

Clinton: We could certainly have done without that.

Spencer: How did you react? Did you think it was all off?

Clinton: No. First of all, I was mad about it, but I also understood the kind of pressures Adams was under. In every democratic system under stress you want to do two things at the same time, hold it together and move it forward - but in doing so you trigger all kinds of identity and interest questions.

Spencer: What do you mean? 
Clinton: I mean what was the Brexit vote [ed. note: the UK referendum to leave the European Union in 2016] about? What does it mean to be British? What does it mean to be in the European Union? What does it mean to be French? What shall we do with our immigrants? Anytime you get something like that, if you want to steer it though, the question is: when do you feed the beast? Do you let people set off the bomb at Canary Wharf and then crack the whip by making it clear to people that if they want peace they have to do this, this, and this? There is no magic formula for dealing with such a situation. You are just sort of dealing with it as you go along.

Spencer: Did it give you more weight in a way because that act [the Canary Wharf bombing] allowed you to lean on the republican movement even harder?

Clinton: Yes, because my view was if they wanted a peace agreement then bombing Canary Wharf had no long-term strategic logic. If they thought that the British were dragging their feet or the British were letting the unionists drag their feet and they did it because they wanted to get everybody's attention, it was very high risk and, thank God, it was not a situation where twenty people were killed [two people were killed and more than one hundred were injured.] $]^{\text {ii }}$. It would seem as though they tried to make it a noisy but low-human impact event, although it was clearly a deliberate provocation too. On that basis, I thought that it probably meant they still wanted to make peace and either had a renegade, or they were giving in, or they were feeding the beast.

Spencer: Were you close to walking away after Canary Wharf?

Clinton: No. I think I figured it right, that both sides still wanted it and that even if they concluded, for whatever reason, that this was needed or that somebody beyond the organization had done it and the people in charge did not want to face the embarrassment of acknowledging that, the underlying fundamentals had still not changed, so we decided to stay 
the course. Now if it had happened two or three more times, it might have been a different story.

Spencer: Was it important for you not to get bogged down in the details of this process because people could then have tried to tie you to intricate questions about policing, decommissioning, prisoners, marches, victims, etc.?

Clinton: It was easier for us than it was for [Prime Minister] Blair because, in law, Northern Ireland was still a part of the United Kingdom and if this was going to get the British Parliament to give their blessing to this peace agreement - which included special relationships with the Republic of Ireland, shared decision-making, majority rule, minority rights, all of that - they were necessarily going to have to be involved more in the detail on areas like policing because that was where British government concessions had to be made. It was more important for us to basically create the conditions that would maximize the chances of making peace and then set up a process that would make sure that a sensible decision would be made. Remember, the United States did not have to live under or live with any of the detail and in some ways if we had tried to over-involve ourselves with the detail it would have undermined our influence. On the other hand, once George Mitchell morphed his role from the Special Envoy for Trade and Investment into the Special Envoy for the peace process, he had to know as much about that as anybody else, and he had to be able to push people to specify how they were for what they were for or against what they were against, and then consider how he could bridge gaps. If we had waded in too hard on one side or the other on some of these issues a) we would have looked tone deaf and arrogant since we did not have to live with the consequences and b) we would have undermined Mitchell's ability to drive people to their own decisions. It's hard enough to sell one of these things under any circumstances but knowing that your own representatives made the deal makes it easier, and once you get close - we found this with the Middle East, too - you may have to weigh in 
because there may be no way to bridge the divide. However, that is an argument for waiting as long as is possible to say you need A, B or C. You have to keep in mind that other people are living with the consequences.

Spencer: The Irish often talked about the power of informal negotiation. Is a lunch, a drink, or a relaxed one-to-one situation a better way of doing business, and, indeed, is it closer to the American way of doing business?

Clinton: I would say yes, although there aren't many people in Northern Ireland and many seem to know each other. But the isolation had been so steep for so long that maybe we did have some effect on changing the culture, and I believe that. I tried to use St Patrick's Day at the White House for this, and we always did the formal thing, where the Irish Taoiseach would show up and give me the shamrock in the Irish crystal during the daytime, and then I would try to have an evening event every year and to invite a fair number of people from the parties and not just the biggest ones and then use those opportunities for me and others to have one-on-one totally off-the-record conversations. Even if we didn't do anything but drink Irish whiskey and talk about our families, it was really important because if you look at all this trouble with nationalism raging in the world today, the success of that strategy requires the objectifying of people. It requires you to become an object defined by your [demographic] characteristics rather than being seen as a human being. If you want to make a peace, you have to melt the iceberg, you have to become a precedent because, in the end, when you put your name on that document it is not worth a nickel if you are not a person of your word.

Spencer: And so therefore trust is central?

Clinton: Yes, and trust is the democratic element in shortest supply today. Then I watched them build it up and I am telling you it is worth more than anything. 
Spencer: What about the symbolism of things like the handshake? Of being seen on the Falls Road [this is the main road through West Belfast's republican neighborhood] shaking the hand of Gerry Adams? How much attention and consideration goes into a gesture like that and how much of it is spontaneous?

Clinton: In my initial forays it was all thought through. When I visited the Shankill [this is the main road through West Belfast's unionist neighborhood.] and the Falls, I wanted the people to see me and that I wasn't running away from Sinn Fein or pretending that they were something they weren't. But I was also saying we have to build a different tomorrow, which was important. It was important to say I was not dumping on, or looking down on, or de-legitimizing the unionists but that they had to find a way to share the future, and so I gave an enormous amount of thought about how to do that and what to say where. We wanted to do a big event in Derry [known formally as Londonderry, this is Northern Ireland's second largest city and is predominantly Catholic.] for obvious reasons and we wanted to do the Christmas tree lighting in Belfast for obvious reasons. I wanted to spend the night as American President at the Europa for obvious reasons [a hotel in Belfast which has a reputation for being the most bombed hotel in western Europe] and I thought about that. I am big on spontaneity when it comes to human contact, but on the first trip we could not afford a wrong step and we couldn't afford to have one side or the other think that we weren't an honest broker, so a lot of it was thought through.

Spencer: In terms of whose hand you shake first, surely that could be interpreted in various ways. So, how did you try and guarantee, as best you could, balance in that situation?

Clinton: My recollection is we got lucky in that the decision we made was based on how to fit the best traffic flow. You could say I just drove into town and I stopped here and then I went there. And that was factually true, given where the airport was. Maybe we would have had to have thought of something else if the airport had been in a different direction 
from town. I don't remember all the conversation that went into it, but we thought that since the United States had long been an ally of the UK and since I came from Northern Irish Protestant stock, that we ought to give a go at Sinn Fein first and reach out to the Catholics.

Spencer: So that was factored into the decision?

Clinton: I just thought it was the easiest thing to do. It was going to be the most newsworthy thing to do. Nobody would have been surprised if an American president shook hands with a unionist, so when I was thinking about this and we were having conversations we came to the decision that people would take our meetings with the unionists more seriously because they would see that we were determined to be fair and we are not just here for a quick trip. My main concern, once you got the first [photographic] shots right, was that the people would then believe that this is a very serious engagement from us and that we had no intention of pushing anything down anybody else's throat. We knew perfectly well that anything agreed would have to be adopted by people in both communities and that once we had done the "peace is here" stuff, .. .movement in this direction had to be real. But, what was most important was that they trusted me and trusted us and believed whatever we said was what we believed, too. If we made a commitment, then we had to keep it.

Spencer: What was the significance of the late-night phone calls on Good Friday for you when you made yourself available all night to address concerns, questions and requests for help to understand the dynamics of what was going from leaders of the political parties? What were you saying in those calls and what were you trying to do?

Clinton: I was trying to pull the ball over the goal line.

Spencer: How?

Clinton: Well, I was very familiar with the issues. I knew where they were. George Mitchell had briefed me up and I trusted him. His patience is unbelievable. In a deal like this, 
if you ever show impatience - and there is a time for impatience, but not when you are hearing the stories for the first time, because then, if you show impatience - it's like saying I am more important than you, which pisses people off. It's like saying: your losses and your family's losses, your side's losses, aren't all that important to me and your aspirations and your dreams, your children's dreams are simply factors in an equation I am trying to work. You can't do that. You have got to be a good listener. Listening is a dignifying, empowering, trust-building experience.

Spencer: But then at what point do you start to press?

Clinton: First of all, there is no hard and fast rule, but when the people you are listening to start to repeat themselves and no new issue is raised, that is worthy of consideration. Then you have to say to people: you can kill this at any time, but if everybody has been heard on everything that matters, we are now going to start making progress or we are not, and, if so, how do you suggest we do that? That's the way you do it. You don't have to insult anybody. I was guided by Mitchell, Tony Blair, and Bertie Ahern as to what they thought I ought to do. I couldn't sleep anyway, and by then I had spent enough time with all the major players that, if I were to call them at three o'clock in the morning my time, it was a way of saying "America really cares about this and we are with you." Maybe it had the dramatic effect. I also knew them all by then because we had been at this for years, so it wasn't like I was some stranger talking. In a way, it was no big deal for David Trimble if I called him because he talked to me all the time. But, on the other hand, if he knew it was 3:00 or 4:00 in the morning, he knew I really did care and I wouldn't leave him in the lurch if he made a certain compromise. Similarly, Gerry [Adams] knew I wouldn't leave him in the lurch if he made a compromise and that was about all I did. The lion's share of the credit goes to the parties and to the people that were on the ground with them working through all the details. 
Spencer: An Irish official said to me the longer you are involved in a process like this the less chance you are going to walk away. Did you see it like that or for you was it based more on the symbolism of events, personal obligation, and responsibility?

Clinton: All of the above but there is something else, and I think secretly all political participants in a peace process hope they may escape this phenomenon, which is that the people who are most likely to get hurt in terms of their long-term political aspirations are those who have worked the hardest to bring about the peace deal. So, for example, John Hume spends his life working on this, but once the peace deal is made people think maybe we had better vote Sinn Fein because they are tougher David Trimble is in a totally different culture full of old-fashioned rigidity and reluctance, but he sticks his neck out and the biggest beneficiary is the guy who comes down on him hardest, Ian Paisley [in the elections following the agreement, the Social Democratic and Labour Party and the Ulster Unionist Party both lost power respectively to Sinn Fein and the Democratic Unionist Party and at the time of writing there has been no functioning government in Northern Ireland for over two years. The issue of trust in Northern Ireland continues to a problem]. After Paisley gets into power he turns out to be pretty responsible and works with [Sinn Fein leader] Martin McGuinness and others, but it is likely that if you do something like this, which so fundamentally changes the established order of things, you have to be prepared for the fact that as the forward-leaner you may be the first one decapitated. Even if people vote for what you ask them to vote for, they can then they say, "OK, we are now in this boat so we had better get the toughest person we can to steer our side of it."

Spencer: Did you think that in getting the extremes into the middle the moderates would get pushed out in the process?

Clinton: I did, and I worried about it. As it turned out, there were times when the government was down [in the polls] and I thought we were going to lose Stormont [Stormont 
Castle is where the Parliament of Northern Ireland meets] and much of that was unavoidable psychologically because when you vote for a new order, as in the case of unionists, by a quite thin majority, you are precarious because a bunch of people who didn't vote for it are going to want to be represented by the most ardent unionists they can find. Those who voted for it wanted the most trenchant representatives to achieve the best deal possible and it's the same on the other side. It's just basic human psychology.

Spencer: If you have two sides in a peace process you have incumbents and challengers where one side wants change and the other resists it, so you have an imbalance to the negotiation system. How do you try and calibrate that?

Clinton: What I tried to do was, first of all, you have to try to get them to tilt it. It's their lives, not ours. What I and our people argued was that, if you are a unionist the reason you should use for changing is that there are certain things that others are going to take away from you, and you know it anyway. All this trouble is bad for you and it's bad for Northern Ireland to be less well off than Ireland. It's bad for you not to have functioning and flowing economics and immigration between the United Kingdom, Northern Ireland, and the Irish Republic. And the demographics are not working for you because the republican community is having a larger average family size and because in order for you to modernize your economy you have to take in immigrants. Nobody knows if it's going to change the demographics in eight years or twelve, but, at some point, the old order is going to be swept away, so it's better for you to get in now and fashion it so it's fair for you whether you are in the majority or the minority and I really pushed that hard.

Spencer: Did you assist Trimble's negotiation position? How did you try and influence him and push this? 
Clinton: When I was trying to influence someone, whoever it was, I tried never to tell them why they should do what I wanted them to do. I spent an enormous amount of time thinking about what I believed their interest was and the people they represented, and I tried to spend whatever time I could to understand how they saw the world, what their responsibility was to their own people and what their long-term goals were. And then I always made an argument [to] whoever I was talking to - whether it was [Russian President] Boris Yeltsin or the parties in the Irish process or [in] South Africa - where I would say, "It seems to me this is what your interest is." If you are going to help other people make peace you have to empower them to do it. Unless you are prepared essentially to take their country over and assume responsibility for its defense and social-economic welfare, you have to empower people.

Spencer: But you also have to get them to face up to their own fear, don't you?

Clinton: Yes, you do, and you have to simplify it. You have to say the role of the United States in the Irish peace process is to maximize the benefits of peace and minimize its perils. This was the case when we made the Wye River accord in the Middle East peace process, ${ }^{\text {iii }}$ which was the last major handover of land, when I said to the guys if they made a final peace deal they were going to kill each other for at least three years and then there would be later attempts to kill both of them. I said my job is to do everything I could to keep them alive and also benefit people.

You can't lie to people because if you pretend there are no downsides to making peace, you look like a fool and people know better if you are in any kind of combustible circumstance. So, my view was that the best thing the United States could do, aside from listen and build trust and make arguments from other people's points of view, was to say, "I may be wrong, but as I see it, it's in your best interests to do X because. .." That is at least what I tried to do and say, "If you do this, I am well aware you are taking a risk and I am 
not." The big risk is that it could cost you your life. [Yitzhak] Rabin was killed because he took a chance on peace, so you have to say the job of the United States and any personal commitment is to maximize the benefits of an agreement and minimize its perils.

Spencer: A lot of this is empathy and putting yourself in people's shoes, but is empathy dangerous in that it can allow people to prevaricate and avoid doing things?

Clinton: Well you know you also have to be brutally frank about what they have to do, which is not pleasant. Any kind of a deal that has got any chance of succeeding in a complex environment will require people to make decisions they would otherwise just as soon not make. You can't avoid that, and you shouldn't be "yes people," but be level about that. The point I am trying to make is that it is important not to promise people things you can't provide. I could promise, in the Irish case, to accelerate trade and investment, create opportunities, etc. But I couldn't promise, for example, that there would never be a renegade faction of the IRA. All you can do is make it clear that whatever the heck happens, I will not be a sunshine friend here and that if you sign up to this deal, I will ride with you right until the end. So, you try to get as much upside and as little downside as is humanly possible.

Spencer: What did you learn from this about negotiation and the art of leadership?

Clinton: I was discovering, first of all, that the more these people really get to know each other the more likely they were to make a deal even though the issues didn't get any easier. I was stunned when I got into the Middle East peace process how much a lot of those people knew each other and what they knew about each other's families, how they tell jokes to each other, and still they couldn't get there. When you think you know a lot of rules about negotiations and you know this, that, and the other, something will come up and show you that you were wrong and underestimating. Some absolutely bone-headed move will come up and show you that a deal you thought was easy actually won't happen. 
Spencer: Is that why, in your view, the Northern Ireland process stuck and the Middle East process did not stick?

Clinton: It began in my opinion with [PLO leader Yassir] Arafat turning down the deal that I got the Israelis to accept at the end of my tenure, and it led to the defeat of the peace forces in Israel, and then he died and the critical powers bifurcated, [as the PLO split into Fatah and Hamas] so they lost the historic chance. He knew it and that was what was so crazy, so maddening. I said, "Do you want to this before I leave office?" and he said, "Yes, because it will be another five or ten years before we get another chance." And it's now been seventeen.

Spencer: Do you think there are ripe moments for a process?

Clinton: Absolutely. If you are the outsider, you can't do for somebody something they don't want to do for themselves. All you can do is make it easier for them to deal with what they are otherwise inclined to do. If you know deep inside that you ought to do this, and you want to do it, and you want to do it for your kids and grandkids, then the United States is in a fairly solid position to make an enormous contribution. But if you are not ready to give up the clenched fist for the outstretched hand there is not much the rest of us can do about it. You can give a lot of speeches and talk about United Nation resolutions, but there is only so much you can do.

Even with carrots and sticks there are limits unless, as I said, you want to take total responsibility for the country. [United States President] Lyndon Johnson once gave a speech when he was in his twenties and was running for Congress in the presence of the Speaker of the House [of Representatives] Sam Rayburn, and Johnson called his opponent all these names and gave this hellfire and brimstone speech, and asked Sam Rayburn what he thought of the speech, And he [Rayburn] said something along the lines of "It was a good speech 
Lyndon, but I have found in a long life that it is best not to tell someone to go to hell unless you can make them go, and that in my experience there are damn few people you can make go to hell." And it's worth remembering because what he is saying is this is part science and part art.

Spencer: Do you mean art in terms of performance?

Clinton: Yes. You also have to have sticks as well as carrots but even the stick should be applied while making it clear that other people have the power in decision-making and the consequences of that will flow.

\section{Conclusion}

As this interview indicates, President Clinton's approach in Northern Ireland was shaped by both motivation and intervention. He promoted the need for greater collaboration and compromise amongst the political parties and his own role was illustrative of an inclusive mediation approach. His approach was also consistent with a more general view he held that peace agreements were ultimately matters of public persuasion, which would help explain the emphasis he gave to motivational speeches and the effort he gave to prodding, cajoling, encouraging and even flattering protagonists to accept risks for peace (Harris 2006: 416). His strategy of engaging across and with the political parties and the British and Irish governments reduced perceptions of bias, and the sense that he was working to a self-serving political agenda. This also enhanced the credibility of America as an honest broker in the peace process.

The interview highlights Clinton's belief in the value of listening, patience, trustbuilding, and inter-personal engagement and being attentive to different political reactions to similar problems. His comments also point to a strategic use of patience and but how endless 
patience too can become a problem. His argument that impatience may become necessary once the parties have made their positions known is perhaps also more complex than it sounds (Mitchell put up with the same positions being repeated for years) because if impatience is impressed too early it can destroy respect, trust and progress. The expression 'when to hold and when to fold' comes to mind here. Clinton emphasised how listening was more likely to yield positive results if part of a dialogue rather than being only a monologue (it is said that Clinton would often let other leaders speak first before he pronounced on policy moves (Harris 2006: 417)); indicating the value of a soft (supportive), rather than hard (coercive), exercise of power (Nye 2005).

In describing his one-on-one contacts with the key players of the peace process, Clinton points to the role of emotional impact and the power of respect that comes from such interaction. His focus on the "big picture" helped him avoid involved getting bogged down on the minutiae of substance (this was not the case in President Carter's peace negotiations with the Israelis and the Egyptians in 1978 where his leadership of that process demanded more intense engagement with detail and substance (Wright 2015)), therefore avoiding the problem of compounding intransigence. A "big picture" emphasis also provided more room for manoeuvring parties and benefited from the ambiguity of the early stages of the process (once the implementation of the agreement came into play and responsibilities became clearer this was far less effective), where rigidity was less prevalent as political parties were trying to adapt to the movement of the process.

Clinton maintained a commitment to engagement despite the challenge of the Canary Wharf bombing and his continued support for the peace process and Sinn Fein's involvement after the bombing enabled Clinton to exercise even more influence over Sinn Fein as a result. This is just one among a number of examples that proved his commitment to help overcome 
obstructions (mainly caused by lack of trust) that were holding the process up (Mallie and McKittrick 2001; Campbell 2007: 2013)

Significantly, much of his commentary in this interview reflects his focus on the psychological dynamics rather than specific policy goals. Perhaps this is not surprising given that Clinton's priority was to appeal to disputants' imaginations and encourage them to focus on the possibilities for positive change. In demonstrating his own commitment to the peace process by taking risks as well as making supportive interventions (even if calculated as with the Adams visa) Clinton was, in turn, able to make reciprocal gestures more likely and so increase his influence in the process. But perhaps we should acknowledge, too, that Clinton's influence had a better chance of success in Northern Ireland given the foundations of a peace process were in place before his involvement (as they were) and therefore that his role came to both reinforce and symbolise the opportunity (ripeness) for change that many were hoping for (the concept of ripeness has been well used in conflict resolution literature and even though there is a tendency to be less forthcoming on where the origins of ripeness might be found, or how the conditions might be created to facilitate it, there are nevertheless useful contributions on how it important it is to be mindful of shifts in the political atmosphere and tentative attempts by participants in conflict to reach out (Haass 1990: 138-150)).

Economic incentives certainly played a role in ending the Northern Ireland conflict and Clinton's appointment of George Mitchell as economic envoy to Northern Ireland (before he became chairman of the negotiations), highlighted the relationship between economic opportunity and political activity. Economic development was an important consideration for Carter in his 1977 initiative on Ireland so investment are have historical precedent here too.

New presidents, especially those of another political party, often take different diplomatic approaches to their predecessors; seeking to demonstrate leadership capabilities on their own terms and which are reflective of policy and personality differences. Because of 
this, supportive diplomacy can change to assertive forms of engagement. This was the case during the post-Good Friday Agreement phase when Clinton's successor, President George W. Bush, took a more authoritative approach and intensified pressure on republicans to commit to decommissioning and to accept new policing and justice arrangements (Clancy 2016), both of which were obstructing progress. In that instance, Bush was less disposed than Clinton to fielding the constant concerns and contentions that arose between the parties but chose to make interventions more in moments of acute difficulty or provocation (particularly in relation to republican criminality). Strategically, Bush would have known it would be unlikely he could exceed the popularity of Clinton on Northern Ireland, but he remained wedded to the peace process and believed he could continue to contribute positively to it (Marsden 2006).

As a peace process advances, understanding and anticipation about what it can and should deliver can lead to possibilities narrowing and allow the dangers of win-lose, zerosum politics to re-emerge, as parties return to the safety of polarised and divisive positions. That is where Northern Ireland is today. Couple that tension with the confusion and fear of Brexit, along the sectarianism that continues to keep Northern Ireland from breaking with the animosities of the past (Independent Reporting Commission 2018), and one can see how a peace process is never conclusively over.

Overall, the success of the peace process in Northern Ireland is representative of its foundations, aspirations, and a collective commitment on the part of the disputants' and their supporters to see conflict ended and, in that, Clinton's role was central. He displayed the “curiosity, ambition and determination" needed to act as a leader of influence (MacMillan 2015: 147), and he was able to cultivate an emotional attachment to the possibilities of peace. From the trust he developed with the political parties he was also able to both motivate and encourage them to accept risks for peace as well as advise, instruct and exert pressure, as was 
the case especially in the final stages leading up to the Good Friday Agreement (Campbell 2007: 295, 315, 413; Campbell 2013: 53, 94, 113).

Clinton also articulated (to the British government) that the achievement of political goals should be given priority over how those political goals are defined, that one should stop talking about what one has done and start talking about what one is going to do (Campbell 2007: 96), and understand that it is important to "never stop communicating" (Campbell 2013: 303). Clinton's skill in keeping the emphasis forward-looking and his ability to give this momentum personal appeal is also highlighted by Tony Blair's strategist and spin-doctor Alistair Campbell who saw Clinton at close quarters throughout the run-up to the Good Friday Agreement. On Clinton Campbell recalls "how brilliant he was at connecting, not just through what he said, but how he said it, through the pictures he painted in words, and through body language, but above all through making the most of what he knew and what people told him. You always had the feeling with Clinton that he was just hoovering up other people's stories and experiences, because they interested him, but also because he could use them" (Campbell 2013: 242).

It may well be the case that Clinton got involved in Northern Ireland primarily because he thought he could make a difference and that he was fascinated by the challenge of trying to resolve the "longest remaining unresolved problem in Europe" (Mallie and McKittrick 1996: 286); that his own motivation was largely personal. But, we should also recognise how he was acting in the long American tradition of promoting peace and democracy too and that his inventions were consistent with broader policy goals of democratic enlargement that he favoured (Dempsey 2004: 200-201).

The importance of motivation and intervention together help us better understand the value of Clinton's role in the Northern Ireland peace process and even though his ability to intervene effectively ended with his presidency in January 2001 it remains notable that 
Clinton still believes in the motivational emphasis. At a commemorative event in Washington in 2018 to mark the twentieth anniversary of the Good Friday Agreement Clinton ignored the problems that were bedevilling the peace process at that point and spoke about how the anniversary offered "an opportunity to recommit to the spirit of courage and co-operation that made the Good Friday Agreement possible in the first place." He advised his audience to "seize the moment" and "move into the future together" (Clinton 2018). It could have been 1995 all over again.

\section{References}

Adams, G. 1996. Before the Dawn. Heinemann: London.

Adams, G. 1997. An Irish Voice. Mount Eagle: Dingle/County Kerry.

Adams, G. 2003. Hope and history: Making peace in Ireland. Brandon: Dingle/County Kerry.

Anderson, D. 1994. 14 May days. Dublin: Gill and Macmillan.

Bardon, J. 1992. A History of Ulster. Belfast: The Blackstaff Press.

Bew, P. and Gillespie, G. 1999. Northern Ireland: A chronology of the Troubles. Dublin: Gill and Macmillan.

Birney T. and O’Neill J. 1997. When the president calls. L'Derry/Northern Ireland: Guildhall Press.

Bloomfield, D. 1998. Political Dialogue in Northern Ireland. Basingstoke: Macmillan Press.

Brinkley, D. (1997) 'Democratic Enlargement: The Clinton Doctrine. Foreign Policy.

Spring (106): 110-127.

Campbell, A. 2007. The Blair Years. London: Hutchinson. 
Campbell, A. 2013. The Irish Diaries (1994-2003). Dublin: The Lilliput Press.

Clancy, M.A.C. 2016. Peace without consensus: Power sharing politics in Northern Ireland. London: Routledge.

Clinton W. J. 1995. Proud traditions coming together. Speech given at the Mackie metal plant in Belfast, Northern Ireland. Available at edition.cnn.com/WORLD/9511/clinton_ireland/transcript.html.

Clinton, W. J. 2004. My life. London: Hutchinson.

Clinton, W. J. 2013. Peacemaking. In Peacemaking in the twenty-first century, edited by J. Hume and T.G. Fraser and L Murray: Manchester: Manchester University Press.

Clinton, W. J. 2018. Bill Clinton says $20^{\text {th }}$ anniversary of Good Friday Agreement is an opportunity to build on peace. 14 March. Available at www.independent.co.uk/news/uk/politics/good-friday-agreement-20th-anniverarybill-clinton-opportunity-for-peace-a8254811.html

Cox, M. (1998) Thinking 'globally' about peace. Politics 18(1): 57-6.

Curran, D. Sebenius, J. K. Watkins, M. 2004. Two Paths to Peace: Contrasting George Mitchell in Northern Ireland with Richard Holbrooke in Bosnia-Herzegovina. Negotiation Journal. 20(4): 513-537

Dempsey, G. T. 2004. From The Embassy. Dublin: The Open Republic Institute.

Dobson, A. 2014. Listening for democracy: Recognition, representation, reconciliation. Oxford: Oxford University Press.

Dorr, N. 2017. The search for peace in Northern Ireland. Dublin: Royal Irish Academy. Dumbrell, J. 1993. The Carter Presidency. Manchester: Manchester University Press. 
Dumbrell, J. 1995. The United States and the Northern Irish Conflict 1969-94: from Indifference to Intervention. Irish Studies in International Affairs $6: 107-125$.

Fearon, K. 1999. Women's Work. Belfast: The Blackstaff Press.

FitzGerald, G. 1991. All in a Life: An Autobiography. Dublin: Gill and Macmillan.

FitzPatrick, M. 2017. John Hume in America. Dublin: Irish Academic Press.

Galinsky, A. D. and Maddux, W. W. and Gilin, D. and White, J. B. 2008. Why it pays to get inside the head of your opponent. Psychological Science 19 (4): 378-384.

Greenstein, F. I. 1994. The two leadership styles of William Jefferson Clinton. Political Psychology 15 (2): 351-361.

Guelke, A. 1996 The United States, Irish Americans and the Northern Ireland peace process. International Affairs 72 : 521-536.

Haass, R. 1990. Conflicts Unending. New Haven: Yale University Press.

Hall, T. 2015. Emotional diplomacy. Ithaca/New York: Cornell University Press.

Harnden, T. 1999. 'Bandit country'. London: Hodder and Stoughton.

Harris, J. F. 2006. The Survivor. New York: Random House.

Hazleton, W. 2000. Encouragement from the sidelines: Clinton's role in the Good Friday Agreement. Irish Studies in International Affairs 11:103-119.

Hennessey, T. 2000. The Northern Ireland Peace Process. Dublin: Gill and Macmillan.

Hennessey, T. 2015. The first Northern Ireland Peace Process. Basingstoke: Palgrave.

Holmes, M. and Yarhi-Milo, K.2017. The psychological logic of peace summits: How Empathy Shapes Outcomes of Diplomatic Negotiations. International Studies Quarterly 61(1): 107-122. 
Independent Reporting Commission. 2018. First Report. 23 October. Available at www.ircommission.org/publications/irc-first-report

Jackson, G. S. M. 2007. Soldier. London: Bantam Press.

Kennedy, E. M. 2009. True Compass. New York; Little Brown.

Lillis, M. and Goodall, D. 2010. Edging towards peace. Dublin Review of Books. Winter Issue 16. Available at www.drb.ie/essays/edging-towards-peace

Lynch, T. J. 2004. Turf war. Aldershot/Hampshire: Ashgate Publishing Limited.

MacLeod, A. 2016. International politics and the Northern Ireland conflict. London: I.B. Tauris.

MacMillan, M. 2015. History's people. London: Profile Books.

Major, J. 1999. John Major: The autobiography. London: Harper Collins.

Mallie, E. and McKittrick, D. 1996. The Fight For Peace. London: William Heinemann.

Mallie, E. and McKittrick D. 2001. Endgame in Ireland. London: Hodder and Stoughton.

Marsden, L. 2006. Promoting Democracy in Northern Ireland: George Bush and the Peace Process. The Political Quarterly. 77 (1): 61-70.

McDaid, S. 2016. Template for peace: Northern Ireland 1972-75. Manchester: Manchester University Press.

McAlpine, A. 1997. Once a jolly bagman. London: Weidenfeld and Nicolson.

Mitchell, G. 1999. Making Peace. London: William Heinemann.

Neustadt, R. E. 1990. Presidential power and the modern presidents. New York: The Free Press.

Nye, J. 2005. Soft power: The means to success in world politics. New York: Public Affairs. 
O’Clery, C. 1997. Daring Diplomacy. Boulder/Colorado: Roberts Rinehart Publishers.

O’Dowd, N. 2010. An Irish voice. Dublin: The O’Brien Press.

O’Grady, J. 1996. An Irish Policy Born in the U.S.A. Foreign Affairs 75(3): 2-7.

O’Hanlon, R. 1998. The new Americans. Colorado: Roberts Rinehart Publishers.

Pope, M. and Pozorski, D. 2009. Interview with Martha Pope and David Pozorski by Brien Williams. George J. Mitchell Oral History Project 45. Available at https://digitalcommons.bowdoin.edu/mitchelloralhistory/45

Powell. J. 2008. Great Hatred, Little Room. London: The Bodley Head.

Renwick. R. 2019. Not Quite A Diplomat, London: Biteback Publishing.

Riley, R. L. 2016. Inside the Clinton White House. Oxford: Oxford University Press.

Seitz, R. 1998. Over here. London: Weidenfeld and Nicolson.

Soderberg, N. 2005. The superpower myth. Hoboken/New Jersey: John Wiley and Sons, Inc.

Soderberg, N. 2015. In America. Edited by S. Farren, and D. Haughey. John Hume: Irish Peacemaker. Dublin: Four Courts Press.

Spencer, G. 2008. The state of loyalism in Northern Ireland. Basingstoke: Palgrave.

Spencer. G. 2010. Managing a Peace Process: an interview with Jonathan Powell. Irish Political Studies. 25 (3): 437-455.

Spencer, G. 2015a. The British and peace in Northern Ireland. Cambridge: Cambridge University Press.

Spencer, G. 2015b. From armed struggle to political struggle. London: Bloomsbury.

Spencer, G. 2019. Inside Accounts: The Irish Government and Peace in Northern Ireland (Vols 1 and 2). Manchester: Manchester University Press. 
Wright, L. 2015. Thirteen Days in September. London: Oneworld.

Zartman, I. W. and Berman, M. R.1982. The practical negotiator. New Haven: Yale University Press.

Zartman, I. W. and Touval, S. 1985. International mediation: Conflict resolution and power politics. Journal of Social Issues 41(2): 27-45.

\footnotetext{
i The support of Edward M. Kennedy, a powerful senator from Massachusetts and scion of the United States' most well-known Irish-American family had been a long-standing opponent of the PIRA who had initially opposed the visa but changed his mind following conversations with John Hume, the leader of Northern Ireland's Social Democratic and Labour Party (SDLP) and representatives of the Irish Government (Kennedy 2009: 460-463). ii John Major of the Conservative Party was Prime Minister of the UK from 1990 until 1997 when he was succeeded by Tony Blair of the Labor Party.

iii The bombing that ended the IRA ceasefire on February 9, 1996 actually took place in the London Docklands, which are outside Canary Wharf. The truck bomb devastated a large area, leaving a 32 foot-wide crater, and caused more than 150 million pounds worth of damage. ${ }^{\text {iv }}$ The Wye River Memorandum was an agreement negotiated in Maryland and signed in the White House by Israeli Prime Minister Benjamin Netanyahu and Palestine Liberation Organization leader Yasser Arafat in October 1998. The memorandum called for the transfer of some land in the West Bank from Israel to the Palestinian Authority.
} 